Pamiętnik Literacki 2015, 1, s. 169-182

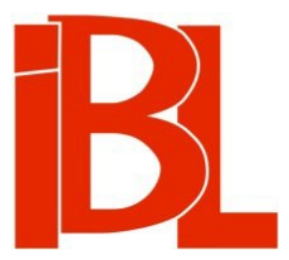

\title{
O tekstach religijnych w XVI-wiecznych elementarzach polskich
}

\author{
Margarita A. Korzo
}




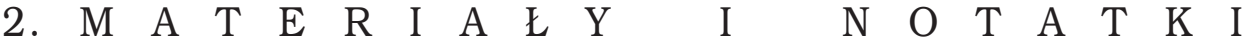

Pamiętnik Literacki CVI, 2015, z. 1, PL ISSN 0031-0514

MARGARITA A. KORZO Institut fiłosofii Rossijskoj akadiemii nauk, Moskwa

\section{O TEKSTACH RELIGIJNYCH W XVI-WIECZNYCH ELEMENTARZACH POLSKICH*}

Do naszych czasów przetrwało niewiele XVI-wiecznych elementarzy polskich i polsko-łacińskich. Większość z nich jest mocno zdefektowana, składa się z zaledwie kilku kartek, wyklejonych z makulatury i opraw druków późniejszych ${ }^{1}$. Z wieku XVII zachowało się znacznie więcej wydań, jakkolwiek ich liczba wciąż jest dość nikła w porównaniu z następnym stuleciem.

Charakterystyczną cechą elementarzy, podobnie jak wszystkich podręczników elementarnych z owych czasów, było zestawianie raczej skromnego materiału gramatycznego ze stosunkowo rozległym wyborem tekstów religijnych. Utarł się szybko zwyczaj, że nawet do akademickich podręczników gramatyki dołączano krótkie modlitwy albo niedługi wykład podstawowych prawd wiary; teksty te były pisane mową wiązaną, najczęściej w formie dystychów. Tak profesor i rektor Akademii Krakowskiej, kanonik Jakub Parkoszowic (zm. ok. 1455), w ułożonym przez siebie traktacie o ortografii zamieszcza m.in. alfabet rymowany, w którym objaśnia zasady polskiej fonetyki, a zarazem - podstawowe prawdy wiary chrześcijańskiej ${ }^{2}$. Analogiczne połączenie spotyka się we wczesnej tradycji czeskiej. Przykładem jest niedatowany elementarz (Abecedár) z początku XVI wieku. Zasługuje on na uwagę jeszcze i $z$ tego powodu, że nie był przeznaczony wyłącznie do nauki w szkole, ale również do użytku domowego ${ }^{3}$.

* Artykuł został przygotowany w ramach stypendium badawczego Rosyjskiej Fundacji Nauk Humanistycznych (RGNF, Moskwa), projekt nr 13-01-00217.

1 Wyczerpujący katalog tych druków - zob. F. Pil a r c zy k, Elementarze polskie. II. Materiały bibliograficzne. Zielona Góra 1990. Na temat zawartości podręczników owej epoki zob. T. Bi eń kows k i, Ksiażki szkolne w Polsce od XVI do połowy XVIII wieku. (Księgoznawcza problematyka badawcza). „Studia o Książce” t. 8 (1978). - I. J a r o s z, Ksią̇ki szkolne $w$ Polsce $w$ wieku XVI. (Zarys problematyki). „Rozprawy z Dziejów Oświaty” t. 21 (1978).

2 Zob. J. Ło ś, Jakóba syna Parkoszowego traktat o ortografii polskiej. W zb.: Materiały i prace Komisji Językowej Akademii Umiejętności w Krakowie. T. 2, z. 2. Kraków 1907, s. 412.

3 Zaznaczono to już na karcie tytułowej: „Chtěl-li by kdo učedlníkem Páně Kristovým býti, ten každej má tuto abecedu mentem uměti. Ty, hospodáři, kup ji do svého domu a vyučuj ji dítky své, i čeládku měj $k$ tomu [Każdy, kto chciałby być uczniem Chrystusa, musi znać to abecadło na pamięć. Ty, gospodarzu, zakup je do swego domu i nauczaj swe dziatki, i czeladkę nakłaniaj do tegol”. Cyt. za: M. D a n̆ k ov á, Cedule rezané na př́jem knih z Kralické tiskárny. „Časopis Matice moravské” t. 68 (1948), nr 1/2, s. 90. 
Praktyka zestawiania nawet specjalistycznych pomocy gramatycznych z mniej lub bardziej rozległymi pouczeniami katechetycznymi stanowiła cechę wszystkich konfesji. Na obszarach protestanckich (ale nie tylko) korzystano $z$ łacińskiej gramatyki Filipa Melanchtona, $z$ którą razem drukowano także jeden $z$ jego wczesnych katechizmów ${ }^{4}$. W wypadku szkoły katolickiej, przeważnie kolegiów Towarzystwa Jezusowego, za przykład może posłużyć nadzwyczaj poczytna gramatyka portugalskiego jezuity Emanuela Alwara (1526-1582/83) ${ }^{5}$, do której aż do XVIII w. dołączano katechizm innego słynnego jezuity - Niderlandczyka Piotra Kanizjusza (1521-1597).

Teksty religijne pełniły tu funkcję podwójną: kształtowały świadomość religijną, a ponadto za ich pomoca przyswajano umiejętność czytania. Nie da się ich więc rozpatrywać w izolacji od materiału gramatycznego, bo stanowiły z nim integralną całość, były często graficznie nie wydzielone, wplecione w tekst czytanek. Stopniowo modlitwy i fragmenty z Pisma Świętego uzupełniano pozbawionymi komentarzy katechizmami w formie pytań i odpowiedzi. XVI-wieczne elementarze polskie wykazują duże podobieństwo pod względem struktury i treści. Analiza zawartych tam tekstów religijnych pozwala w przybliżeniu określić możliwy kragg źródeł, a także (jakkolwiek dość ostrożnie) ustalić konfesyjne oblicze tych podręczników.

W średniowieczu rolę elementarza odgrywały niewielkiego rozmiaru (ok. $20 \times$ $15 \mathrm{~cm}$ ) tablice $\mathrm{z}$ alfabetem (w Niemczech - Lestäflein, ABC-Täfelchen; w Anglii hornbooks), znane w tradycji europejskiej z około XII stulecia. Około wieku XV zamieszczano na nich modlitwy Pater noster, Ave Maria i Credo, czyli teksty, które wierni powinni byli recytować lub śpiewać w trakcie nabożeństwa. Najwięcej tablic z tego okresu zachowało się z terenów obecnej Francji. W najwcześniejszych wydaniach (np. Abecedarium cum precibus. Ulm 1470) wybór owych tekstów został znacznie poszerzony i zawierał, oprócz alfabetu i wspomnianych Pater noster, Ave Maria i Credo, także śpiewy liturgiczne: Magnificat (Łk 1, 46-55), kantyk Symeona Nunc dimittis (Łk 2, 29-32), pieśn trzech młodzieńców Benedicite, omnia opera Domini... (Dn 3, 57-88; 3, 56), hymny Veni, Sancte Spiritus i Gloria in excelsis Deo, antyfonę Salve Regina, introit Requiem aeternam dona eis Domine ${ }^{6}$. Wybór tekstów religijnych $\mathrm{w}$ takim układzie można umownie nazwać modelem liturgicznym.

Drugi model to wybór tekstów używany w średniowiecznej katechezie parafialnej. Spotykamy go m.in. w Ortografii (1514-1515) słynnego prawnika i gramatyka Stanisława Zaborowskiego (zm. ok. 1530), wydanej w krakowskiej oficynie Floriana Unglera ${ }^{7}$. Uważa się, że gatunek podręcznika elementarnego, który dominował

Może zawierały go również Elementa Latinae grammatices (Kraków: Hieronim Wietor, 1526), których unikat znajduje się w zbiorach Uniwersytetu w Uppsali. Zob. Sprawozdania z poszukiwań $w$ Szwecji dokonanych z ramienia Akademii Umiejętności przez Eugeniusza Barwińskiego, Ludwika Birkenmajera i Jana Łosia. Kraków 1914, s. 311.

5 E. Alvarus, De institutione grammatica. Olisipo 1572.

6 Zob. H. Mülle r, K.-A. Wir th, Fibel (ABC-Buch). Hasło w: Reallexikon zur deutschen Kunstgeschichte. Hrsg. vom Zentralinstitut für Kunstgeschichte München. Redaktion K.-A. W ir th. T. 8. München 1984, szp. 680-688.

7 Korzystam z wyd. 2: S. Za b o r o w s ki, Orthographia seu modus recte scribendi et legendi Poloni- 
do czasów Komisji Edukacji Narodowej, wiele zawdzięcza właśnie dziełu Zaborowskiego. Wspomina on w przedmowie, że już wcześniej istniały drukowane elementarze w języku polskim; żaden $z$ nich nie jest obecnie znany. Zaborowski, być może, korzystał z rękopiśmiennych pomocy gramatycznych, zarówno łacińskich, jak i polskich. Jego wybór tekstów religijnych (k. 5-5v) składa się z modlitw Ojcze nasz, Zdrowaś Maryjo (w wersji skróconej), Wierzę, po czym następuja, w formie rymowanej: Dekalog, podwójne przykazanie miłości, prawo naturalne (,złota zasada postępowania”) i lista grzechów śmiertelnych. Ten porządek odpowiada tzw. modłom katechizmowym, odmawianym $z$ ludem przez kapłana po kazaniu i przyswajanym przez wiernych ze słyszenia ${ }^{8}$. Nie towarzyszył tym modłom żaden wykład ani komentarz. Średniowieczna katecheza parafialna, która przybrała swój ostateczny kształt po soborze laterańskim IV (1215), służyła za model dla pierwszych drukowanych elementarzy i pomocy gramatycznych w języku polskim, dobór zaś tekstów pozbawiony był jakichkolwiek cech autorskich.

Oprócz rodzimej tradycji rękopiśmiennej pewien wpływ na układ utworów religijnych w elementarzach polskich mogła wywrzeć tradycja czeska. Najstarszy ze znanych druków w języku czeskim ukazał się w oficynie Jana Günthera w Prościejowie i datowany był na 1547 rok. Slabikár Cžesky a giných náboženstwij počátkowé: Kterýmžto wěcem Dijtky Křestianské hned zmladosti učeny býti magij poszerza wybór, dodając Magnificat, kantyk Symeona i tzw. dopełnienie sprawiedliwości (Doplnéní spravedlnosti) - fragment z kazania Chrystusa na Górze (Mt 5-7). Istotną cechą tego druku jest wzmianka o sakramentach chrztu i Wieczerzy Pańskiej (co jednoznacznie zalicza elementarz do tradycji protestanckiej) oraz o „władzy kluczy”, czyli odpuszczeniu grzechów ${ }^{9}$. Sakramenty, błogosławienie pokarmów i modlitwa dziękczynna po jedzeniu nie stanowiły jednostek nauczania parafialnego w okresie dawniejszym.

Warto nadmienić, że nawet w piśmiennictwie wczesnoreformacyjnym sakramenty nie należały do ogólnie przyjętego modelu wykładu materiału katechizmowego. Wprowadza je po raz pierwszy Johannes Agricola (właśc. Johannes Schneider; 1494-1566) w Elementa pietatis congesta (1527), następnie - Wolfgang Capito (1478-1541) w Kinder Bericht und Fragstücke von gemeinen Punkten christlichen Glaubens (1527), Johannes Brenz (1499-1570) we Fragstück des christlichen Glaubens (ok. 1527-1528), Johannes Oekolampad (właśc. Johannes Huschin; 14821531) we Frag und Antwort (przed 1529) ${ }^{10}$. Dopiero po Matym katechizmie Marcina Lutra z 1529 r. stają się one nieodzowną częścią składową katechizmów protestanckich. W elementarzach $z$ terenów Niemiec rozdziały o sakramentach spoty-

cum idioma quam utilissimus. Kraków: Jan Haller, 1518. Przedruk części katechetycznej z wyd. 1: W. Wy dra, W. R. Rze p ka, Chrestomatia staropolska. Teksty do roku 1543. Wyd. 3. Wrocław 2004, s. 315-317.

8 Zob. L. Bernacki, Najdawniejszy pomnik katechizmu polskiego. „Pamiętnik Literacki” 1910, Z. 2.

9 Zob. J. Ku bále k, J. He n d ri ch, F. Ši me k, Naše slabikáře. Od nejstarší doby do konce stoleti XVIII. Praha 1929, s. 301-311.

10 Zob. F. C o h r s, Die evangelischen Katechismusversuche vor Luthers „Enchiridion”. T. 4: Undatierbare Katechismusversuche und Zusammenfassende Darstellung. Berlin 1902, s. 285-287. 
kamy w Eyn Bökeschen vor de leyen unde kinder (Wittenberg: [Hans Weiss], 1525) ${ }^{11}$ i Educatio doctrinae puerilis (Marburg: Andreas Kolbe, 1549) ${ }^{12}$.

Zbliżony do czeskiego Slabikára z 1547 r. wybór tekstów religijnych odnajdujemy w wydaniu poznańskiego drukarza Piotra Sextilisa Nauka ku czytaniu dziatkam małym pisma polskiego (1556) ${ }^{13}$. Wiesław Wydra uważa, że liczne bohemizmy świadczą o sięganiu redaktorów podręcznika do źródeł czeskich i że druk Sextilisa przeznaczony był dla wyznawców Jednoty braci czeskich osiadłej w Polsce ${ }^{14}$. Ponadto poznański drukarz korzystał z przekładu psalmów Walentego Wróbla z r. około 1528, który zyskał rozgłos pierwotnie w wersji rękopiśmiennej i ukazał się drukiem dopiero w 1539 r. w oficynie Heleny Unglerowej, wdowy po Florianie ${ }^{15}$. Pewne niuanse tekstów religijnych występujących w podręczniku Sextilisa odzwierciedlają specyfikę polskiego (a także i czeskiego) średniowiecznego nabożeństwa. Tak więc druga część modlitwy Zdrowaś Maryjo zawiera nie mające odpowiednika w tekstach biblijnych błaganie skierowane do matki Bogurodzicy - św. Anny („I błogosławiona niechaj będzie najuczliwsza Matka Twoja, święta Anna, z który krom zmazy poszło ciało Twoje dziewicze") ${ }^{16}$. Zdrowaś Maryjo w takiej wersji spotykamy również w późniejszych polskich modlitewnikach ${ }^{17}$.

Podobny wybór tekstów religijnych (Ojcze nasz, Zdrowaś Maryjo, Skład Apostolski, Dekalog, przykazanie miłości, uczynki miłosierdzia, siedem grzechów śmiertelnych, dary Ducha Świętego, błogosławieństwa, modlitwy do Ducha Świętego, Magnificat i psalm 130 〈129〉) występuje, z pewnymi uzupełnieniami, w szeregu wydań późniejszych ${ }^{18}$. Sięganie do modelu średniowiecznej katechezy parafialnej może świadczyć, iż owe podręczniki powstawały w ramach tradycji katolickiej.

Ponadto mamy do dyspozycji szereg fragmentów XVI-wiecznych elementarzy polskich albo polsko-łacińskich, jednak wchodzące w ich skład teksty religijne nie odpowiadają opisanym tutaj modelom. Pod względem treści da się je umownie podzielić na dwie grupy.

Pierwszą stanowia podręczniki wzorujące się na Małym katechizmie Lutra. W tym wypadku konfesyjne oblicze elementarzy jest dość wyraźne. Teksty religijne

11 Zob. L. Boy er, Drei kaum bekannte Abc-Büchlein aus dem 16. Jahrhundert. W zb.: Geschichte der Fibel. Hrsg. A. Grö m ming e r. Frankfurt am Main 2002, s. 228.

12 Educatio doctrinae puerilis. Kinderlehre in deutscher und lateinischer Sprache 1549. Herausgegeben und mit einem Nachwort versehen von J. Schilling. Marburg 1987.

13 Podobizna fototypiczna unikatu ze zbiorów Herzog August Bibliothek w Wolfenbüttel (sygn. A:63 Gram.) w dodatkach do artykułu: J. Pirożyński, O poznańskim drukarzu Piotrze Sextilisie z Obrzycka i o polskich elementarzach XVI w. „Studia Historyczne” 1985, z. 1. W. Wy d ra, O najdawniejszej drukowanej ksiażce w Poznaniu. Poznań 2003, s. 21-23.

Zob. ibidem, s. 18-19.

Teksty staropolskie przytaczane są w pisowni zmodernizowanej.

17 Zob. E. Kę d els k a, „Ave Maria” $i$ hasła „maryjne” $w$ słownikach polskich i czeskich XVI $w$. „Slavia Occidentalis" t. 50 (1993), s. 16.

18 Do tej linii podręczników dają się zaliczyć: Nauka ku czytaniu pisma polskiego dla panienek młodych. [Kraków]: Marcin Filipowski, 1622 (Bibl. Uniwersytetu Warszawskiego, Sd.712.175). - Dla dziatek nauka czytania pisma polskiego. Wilno: b.dr., 1633 (Bibl. Jagiellońska, 51965 Ifasc.). - Nauka czytania pisma polskiego dla małych dziatek. Kraków: b.dr., 1710 (Muzeum Książki, Rosyjska Bibl. Państwowa, $8^{\circ}$.polsk.). - [Elementarz]. Gdańsk: Jan Friderik Bartels, 1766-1770(?) (Bibl. Jagiellońska, 586064 I). 
podane są w kolejności: Dekalog, Skład Apostolski, Ojcze nasz, fragmenty o sakramencie chrztu (Mt 28, 18-20; Mk 16, 15-16), ,władzy kluczy” (Mt 18, 18; J 20, 22-23) i sakramencie Wieczerzy (Mt 26, 26-29) - owa kolejność miała u Lutra istotne uzasadnienie teologiczne ${ }^{19}$. Podręczniki te zawierały również modlitwy z Małego katechizmu, które należało odmawiać rano i wieczorem, a także - ułożone na podstawie psalmów - błogosławienie pokarmów (Ps $145\langle 144\rangle, 15-16)$ i podziękowanie po jedzeniu (Ps $118\langle 117\rangle, 1 ; 147\langle 146-147\rangle, 9-11)$.

Do tej grupy zalicza się Nauka krótka ku czytaniu pisma polskiego, która najprawdopodobniej wyszła spod prasy krakowskiej Drukarni Łazarzowej Jana Januszowskiego w drugiej połowie XVI wieku ${ }^{20}$. Zachowała się jako makulatura, wyklejona przez Żegotę Paulego w 1877 r. z nieznanej oprawy - sa to fragmenty korektowej, jednostronnie zadrukowanej odbitki (nie rozcięty arkusz składki A), obejmującej część karty tytułowej, 3 całe strony oraz 8 różnej wielkości fragmentów kart. Jedna $z$ nich zawiera fragment drzeworytu przedstawiającego koguta ${ }^{21}$. Druk nie przekraczał objętości 16 kart.

Elementarz miał rozbudowana partię katechizmową, o czym świadczy fakt, iż na zachowanych kartach poszczególne fragmenty druku nazwane zostały „częściami katechizmu”. Jest ich razem 6 (o takiej kompozycji mówi już krótka uwaga wstępna na karcie 3), składają się one tylko ze sformułowań poszczególnych prawd wiary i nie zawieraja żadnego wykładu. Zachowały się przykazania Dekalogu (od szóstego po dziesiąte), fragment Credo, 3 ostatnie zwrotki Modlitwy Pańskiej z doksologia, urywek „o władzy kluczy” i koniec spowiedzi powszechnej („, ...) wa Bożego proszę, abyś cie〈...〉 grzeszyli, słowem Bożym po〈...〉rzyli, ja chcę żywota mego grzesznego za pomoca Bożą polepszyć, a grzechów się na potym warować. Amen"). W najlepszym stanie jest „szósta część katechizmu: O wieczerzy Pańskiej”, a także 5 modlitw, które dosłownie odpowiadają modlitwom występującym w polskich tłumaczeniach Małego katechizmu ${ }^{22}$.

Analogiczne tendencje - czyli podanie materiału religijnego według schematu Małego katechizmu wraz z ułożonymi przez Lutra modlitwami - spotykamy na terenach Niemiec dość wcześnie ${ }^{23}$. Cechowały one również pewne elementarze dru-

Zob. Evangelischer Gottesdienst. Quellen zu seiner Geschichte. Hrsg. W. H e r b s t. Wyd. 2. Göttingen 1992, s. 69-87.

Bibl. Jagiellońska, Cim. 764. Opis: K. Estreich er, Bibliografia polska. T. 23. Kraków 1910, s. 62. - F. Pil a r c zy k, Elementarze polskie od ich XVI-wiecznych początków do II wojny światowej. Próba monografii księgoznawczej. Zielona Góra 2003, s. 377, poz. 1312. Do książki Pilarczyka odsyłam dalej skrótem P, po którym podaję numer stronicy i, ewentualnie, pozycji bibliograficznej. Zob. Katalog poloników XVI wieku Biblioteki Jagiellońskiej. T. 2. Red. M. Mali c ki, E. Zw in ogrodzka. Kraków 1994, s. 58, poz. 1708. - P 71. Autor hasła Elementarz w Encyklopedyi wychowawczej (Red. J. T. Lu b o mirski [i in.]. T. 3. Warszawa 1885, s. 477-478) oraz J. Ma d eja (Elementarze, ich dzieje, rola i stan wspótczesny. Katowice 1946, s. 13-14) uważają, że druk ukazał się w Królewcu u J. Daubmanna. Madeja nawet twierdzi, iż kompletny egzemplarz znajdował się w zbiorach Trinity College w Cambridge. Na razie nie udało się go odnaleźć.

Enchiridion. Catechismus mały prze plebany i kaznodzieje niedouczone, i lud prosty. Królewiec: Jan Daubmann, 1562, k. 47v-50v. - Katechismik, albo Nauka krześciańska, przez D. Marcina Luthera, zacnego teologa, napisany. Toruń: Andrzej Koteniusz, 1591, k. C7-C8v. - [Enchiridion]. Królewiec: Jerzy Osterberger, 1593, k. F7v-Gv.

Das Alphabetbüchlin. Marburg: Franciscus Rhode, 1533. - Dwa podręczniki V. Ickels a me- 
kowane w języku chorwackim, zarówno cyrylica, jak i głagolicą ${ }^{24}$; w tradycji czeskiej katechizm ojca reformacji wywarł znaczący wpływ na podręczniki elementarne Jednoty braci czeskich, które publikowano na przełomie XVI i XVII w. po czesku (Začátkové učení dítek krestanských) i w wersji łacińskiej (Christianae iuventutis instituendae rudimenta) ${ }^{25}$.

Zauważmy na marginesie, że w Polsce modlitwy z Małego katechizmu występują ponadto w dość popularnych w XVI w. wokabularzach albo rozmówkach polsko-niemieckich, czyli w podręcznikach służących do nauki języków obcych. Pierwsza edycja datowana jest na 1522 lub 1523 rok $^{26}$, kolejna - na 1539 rok $^{27}$. O ich poczytności świadczą chociażby liczne przedruki wokabularzy ${ }^{28}$ i szerokie geograficzne rozprzestrzenienie wydań, sięgające terenów współczesnej Ukrainy Zachodniej ${ }^{29}$. Zamieszczony w nich materiał gramatyczny był o wiele obszerniejszy od tego w książkach elementarnych. Drukowano w wokabularzach również wyjątek z czytanki o Marchołcie i królu Salomonie ${ }^{30}$, wzory listów, ewentualnie - kilka pobożnych pieśni. Materiał religijny składał się $z$ nieco poszerzonych modlitw Lutra, Ojcze nasz, dziesięciorga przykazań i Credo.

Do drugiej ze wspomnianych grup elementarzy polskich należą teksty religijne, których skład nie odpowiada opisanym modelom. Trzeba by tu zaliczyć fragmenty elementarza polsko-łacińskiego z r. około 1550, wytłoczonego - być może - w krakowskiej oficynie Łazarza Andrysowica ${ }^{31}$. Jest to wydobyta $z$ oprawy makulatura: karta [1], częściowo uszkodzona, oraz blisko jedna czwarta karty poprzedzającej ${ }^{32}$. Fragment zawiera sylaby dwuliterowe, ostatnią zwrotkę „złotej zasady postępowania” (Mt 7, 12), „wypełnienie zakonu” (Rz 13, 10), spotykana już w podręczniku Sextilisa rymowana „,summę zakonu” (na podstawie Łk 6, 31); dalej następuja tematycznie podzielone cytaty z Nowego Testamentu, które da się łatwo zidentyfiko-

ra: Lesebüchlein i Die rechte weis aufs kůrtzist lesen zu lernen (Marburg: Franciscus Rhode, 1534).

24 Tybinga: Primož Trubar, 1561 (dwie edycje - cyrylicka i głagolicka); Tybinga: b.dr., 1564 (czcionka mieszana - cyrylicka, głagolicka i łacińska). Zob. A. A. Kr u m ing, Pierwopieczatnyje sławianskije bukwari. W zb.: Fiodorowskije cztienija 1983. Ried. Je. L. Niemirowskij. Moskwa 1987, s. 79-80, 95-96, 99-100. - S. O. Wi a ł ow a, Iz istorii głagoliczeskich bukwariej. „Kniga” t. 77 (1999).

Zob. M. B o hat c o vá, Ediční program ivančické a kralické tiskárny bratrské. „Z kralické tvrze” t. 10 (1978-1979), s. 16-17. Kraków: Florian Ungler (zachowała się we fragmencie: Bibl. Jagiellońska, Cim. 5489). Kraków: Hieronim Wietor (Bibl. Czartoryskich, Cim. 609 I). Tytuł podał Wietor w przedmowie w podwójnej wersji: Ksiażki polskie i niemieckie oraz Książki, albo Oracjonalik. Królewiec: Jan Daubmann, 1558, 1566, 1571; Jerzy Osterberger, 1580, 1587, 1595; Marcin Rode, 1607. - Toruń: Andrzej Koteniusz, 1590, 1596, 1603; Augustyn Ferber, 1611. - Wrocław: Jerzy Baumann, 1615, 1631, 1641.

Zob. Estreicher, op. cit., t. 33 (1939), s. 234-238. - A. Lewicka-Kamińska, Pod jakim tytutem ukazał się „Wokabularz” Wietora? „Przegląd Biblioteczny” 1961, z. 2.

30 Edycja drukowana tej apokryficznej powieści ukazała się pod tytułem Rozmowy, które miat król Salomon madry z Marchottem grubym a sprosnym, a wszakoż, jako o niem powiedaja, barzo z wymownym (Kraków: Hieronim Wietor, 1521).

31 Bibl. Jagiellońska, Cim. 0.912. Pil a r c zy k (P 334, poz. 642) również uważa, iż chodzi o oficynę Ł. Andrysowica. Stary katalog kartkowy Biblioteki Jagiellońskiej podaje H. Wietora.

Zob. Katalog poloników XVI wieku Biblioteki Jagiellońskiej, t. 1 (1992), s. 210, poz. 684. 
wać: Perfectio Legis (Rz 10, 4), Voluntas Patris (J 6, 40), Vita aeterna (J 17, 3), Dilectio Dei erga nos (J 3, 16), Christi benigna invitatio (Mt 11, 28).

Franciszek Pilarczyk (P 71) wysunął przypuszczenie, iż „zachowany tekst sugeruje, że całość była połączeniem elementarza $z$ katechizmem". Jakkolwiek ułamek druku jest dość mały, można $z$ dużym prawdopodobieństwem stwierdzić, na jakim modelu wzorowali się jego redaktorzy, ponieważ analogiczne pod względem treści elementarze spotykamy we wczesnoreformacyjnym piśmiennictwie w Niemczech.

Chodzi tu o popularne „Spruchbücher”, których powstanie wiele zawdzięcza pracom Filipa Melanchtona ${ }^{33}$ : właśnie one stanowiły wzór dla wszystkich późniejszych wydań tego typu ${ }^{34}$. Składające się $z$ tematycznie uporządkowanych, nie komentowanych ustępów biblijnych „Spruchbücher” były wykorzystywane tak w nauczaniu szkolnym, jak i w domu - dla formacji duchowej i dla nabożeństwa prywatnego. Reformatorzy pierwszej generacji zdawali sobie sprawę $z$ tego, że niełatwo jest sporządzić zwięzły wykład podstawowych prawd wiary na użytek zarówno praktyki szkolnej, jak domowej. Tę funkcję katechizmu uniwersalnego pełniły właśnie „Spruchbücher” 35 .

Zgodnie $\mathrm{z}$ intencją reformacyjnych pedagogów chodziło o uczenie się fragmentów biblijnych na pamięć. Poczytność „Spruchbücher” da się wytłumaczyć wyjątkową rolą nadawaną Pismu Świętemu w duchowej formacji wiernych: traktowano je jako wartość samą w sobie, a nie tylko jako ilustrację do poszczególnych pouczeń katechetycznych. Doceniając znaczenie zapamiętywania tekstów biblijnych w procesie edukacyjnym, Luter dwukrotnie opublikował w 1526 r. Ein Büchlein für die Kinder gebessert und gemehrt. W roku zaś 1529, poza wydaniem swych katechizmów, ułożył tzw. Kinderbibel - w ciągu XVI w. ukazało się jej 25 edycji w języku niemieckim i 4 po łacinie ${ }^{36}$. Słynny Haustafel reformatora - wybór cytatów biblijnych o obowiązkach rozmaitych stanów i grup społecznych, zamieszczany jako dodatek do wszystkich wydań Małego katechizmu - także pomyślany był jako „Memorierstoff”, uczono go bowiem na pamięć ${ }^{37}$. Szerokiemu rozprzestrzenianiu się Pisma Świętego służyły również pieśni religijne, tworzone przez reformatorów różnych odcieni.

Układ „Spruchbücher” przeszedł w XVI w. pewną ewolucję. Opracowane przez Melanchtona Pouczenie dla wizytatorów (Unterricht der Visitatoren, 1528) wylicza szereg psalmów, których miały się nauczyć dzieci w szkole pod kierownictwem

Zob. M. H. J u n g, Frömmigkeit und Theologie bei Philipp Melanchthon. Das Gebet im Leben und in der Lehre des Reformators. Tübingen 1998, s. 218.

Zob. Ch. W e is m a n, Die Katechismen des Johannes Brenz. T. 1: Die Entstehungs-, Text- und Wirkungsgeschichte. Berlin - New York 1990, s. 205, 486.

Zob. J. Schoe11, Spruchbuch. Hasło w: Religion in Geschichte und Gegenwart. Wyd. 2, zmien. Hrsg. H. Gunke1, L. Zs charnack. T. 5. Tübingen 1931.

Zob. A. E. Schne p per, Goldene Buchstaben ins Herz schreiben. Die Rolle des Memorierens in religiösen Bildungsprozessen. Göttingen 2012, s. 78-80, 86, 94-99.

Dzieci, w myśl poglądów pedagogicznych Lutra, mogłyby przyswajać biblijne sentencje już w trakcie kazania i później recytować z pamięci w gronie domowników, przyczyniając się też w ten sposób do ich formacji duchowej. W przedmowie do Deutsche Messe (1526) reformator charakteryzuje możliwą metodę przyswajania porównując biblijne sentencje do monet, które dzieci powinny tematycznie sortować i wkładać do różnych sakiewek. Zob. Martin Luther deutsch. Die Werke Martin Luthers in neuer Auswahl für die Gegenwart. Hrsg. K. Al a n d. T. 6: Kirche und Gemeinde. Stuttgart-Göttingen 1966, s. 92-93. 
nauczyciela ${ }^{38}$. Owe psalmy, a także wybór ustępów z Księgi Przysłów i Mądrości Syracha stanowiły na początku trzon „Spruchbücher”. Z czasem składający się na nie materiał religijny zostaje tematycznie uporządkowany. Przeważaja czytania biblijne podane w porzadku roku liturgicznego. Zdaniem Johanna M. Reua, dopiero od drugiej połowy lat siedemdziesiatych XVI stulecia porządkowano passusy z Pisma Świętego również według kolejności poszczególnych części katechizmu ${ }^{39}$. Jakkolwiek pojedyncze przykłady takiej kompozycji spotykamy już znacznie wcześniej ${ }^{40}$.

Fragment elementarza krakowskiego z około 1550 r. powtarza w całości wstępną część rozdziału Spruchsammlung z małej czytanki Syllabas per discendi Ratio. Pueris analphabetis, ułożonej około 1526 r. przez sympatyka idei protestanckich, Benedykta Otha. Zajmował on wtedy posadę nauczyciela w formalnie jeszcze katolickiej szkole w Lipsku (Schola Senatus Lipsensis, inaczej - Leipziger Nikolaischule). Mamy do dyspozycji tylko drugą edycję czytanki (Leipzig: Melchior Lotterus, $1527)^{41}$. Ze sporzadzonej przez Łukasza Otha, będacego bratem Benedykta, przedmowy wynika, iż brał on czynny udział w redagowaniu drugiego wydania; mógł on również poprawiać Spruchsammlung. Rozdział ten składa się z dwóch części. Pierwszą stanowią modlitwy Ojcze nasz, Zdrowaś Maryjo i Wierzę, psalmy 67 i 127, przykazania Dekalogu. Część druga to tematycznie uporzadkowane i nie komentowane ustępy z ksiąg Nowego Testamentu w kolejności odzwierciedlającej historię Zbawienia: Summa Legis (Mt 7, 12; 22, 37-39; Rz 13, 9-10), Perfectio Legis, Voluntas Patris, Vita aeterna, Dilectio Dei erga nos, Christi benigna invitatio, Mediator Christi (J 14, 6; Mt 7, 7; 21, 22), Propiciatio pro peccatis (1 J 2, 1-2; Mt 9, 13), Confessio Christi (Mt 10, 32; Rz 10, 10), Crux ferenda (Mt 10, 38), Adversus traditiones humanas (Mt 15, 13), Offensio parvulorum (Mt 18, 6-7), Christi praesentia (Mt 18, 20), Merces renuntiantium omnibus propter Christi nomen (Mt 19, 29; 22, 14), lista ośmiu błogosławieństw ewangelicznych, Christi venturus iudex (Mt 25, 31-46).

Ferdinand Cohrs przypuszcza, że bracia Otho mogli się wzorować na podręczniku gramatyki Filipa Melanchtona, który ukazał się w 1523 r. po łacinie, pod tytułem Enchiridion elementorum puerilium, i za rok - w języku niemieckim, jako Handbüchlein wie man die Kinder zu geschrift und lese halten soll ${ }^{42}$. Melanchton zaznacza w przedmowie, że chodzi mu nie tyle o nauczanie języka, ile o to, by dzieci wzrastały w pobożności. Wybór tekstów religijnych zawierał modlitwy Ojcze nasz, Zdrowaś Maryjo i Wierzę, psalm 66, dziesięcioro przykazań, kazanie Chrystusa na Górze, zasady życia chrześcijanina z Rz 12, opis Ostatniej Wieczerzy na podstawie $\mathrm{J} 13$ oraz psalm 127. Jako dodatek Melanchton zamieścił Dicta Sapientum, Erasmo Roterodamo interprete (moralizujące sentencje myślicieli różnych epok, w tym greckich), a także wybór modlitw w porządku horae canonicae, które ułożył osobiście dla prowadzonej przez siebie szkoły; modlitwy powinny były „obejmować” przebieg całego dnia uczniów. Cechę charakterystyczną tego podręcznika stanowi połączenie

Zob. D. Martin Luthers Werke. Kritische Gesamtausgabe. Dział 1, t. 26. Weimar 1909, s. 239. J. M. Reu, Quellen zur Geschichte des biblischen Unterrichts. Gütersloh 1906, s. LXXV-CIII. M. Bu c e r, Der kürtzer Catechismus. Straßburg: Wendel Rihel, 1543.

Przedruk: Cohrs, op. cit., s. 176-181.

Przedruk obu wersji: Supplementa Melanchthoniana. T. 5: Schriften zur praktischen Theologie, cz. 1: Katechetische Schriften. Hrsg. F. C o hr s. Frankfurt 1968, s. 20-56. 
jednostek katechetycznych $\mathrm{z}$ tekstami biblijnymi i modlitwami oraz całkowita rezygnacja autora $\mathrm{z}$ ich wykładu ${ }^{43}$.

Pierwsza część Spruchsammlung w czytance braci Otho w istocie wykazuje duże podobieństwo do Enchiridionu [...] Melanchtona. Prawie wszystkie cytaty biblijne pochodza z Nowego Testamentu w przekładzie Erazma z Rotterdamu (1516). Psalmy zaś 67 i 127 cytowane są w wersji odmiennej zarówno od Wulgaty, jak i od Erazma, która odpowiada zamieszczonej w edycji Enchiridionu [...] z około 1525 roku. Druk ten zawiera ponadto wstępne sentencje z rozdziału Dicta Sapientum podręcznika Melanchtona ${ }^{44}$.

Bracia Otho mogli sięgać także do niewielkiej książeczki Etliche spruch darynn das gantz Christlich leben gefasset ist, którą Melanchton sporządził przed 1527 ro$\mathrm{kiem}^{45}$. Jest to w istocie pierwsze wydanie należące do typu ewangelicznych „Spruchbücher" 46 i właśnie ono posłużyło za wzór dla wielu książek tego rodzaju ${ }^{47}$.

Poszerzona edycja z około 1529 r. nie jest dostępna; edycja z 1527 r. składa się z 22 fragmentów z ksiag Starego Testamentu i 46 - z Nowego, które podzielone są tematycznie na 6 części: Von Busse und Furcht des erschrecklichen Zorns Gottes und dem Anfang christlichen Lebens, Vom Glauben, Von Creutz und Übung des Glaubens und Gebett, Von Übung des Glaubens in Sorge der Nahrung oder dergleichen zeitlichen Anliegen, Von guten Werken, Gehorsam, gegen die Obrigkeit, von Liebe des Nächsten, von Keuschheit, Vom ehelichen Leben. Dodatki zawierają rozważania Unterschied zwischen weltlicher und christlicher Frömmigkeit, modlitwy na rano i wieczór, psalm 127.

Jakkolwiek „Spruchbücher” braci Otho oraz Melanchtona należą do tego samego gatunku, ich układ wewnętrzny bardzo się różni. Dla polskiej tradycji i dla elementarza polsko-łacińskiego z około 1550 r. właśnie praca braci Otho odegrała rolę pewnego wzorca do naśladowania.

Do gatunku „Spruchbücher” da się zaliczyć (choć z pewnymi ograniczeniami) dość duży jak na te czasy, bo 43-kartkowy dwujęzyczny podręcznik Elementaria institutio Latini sermonis, et pietatis Christianae z r. 1575, wytłoczony przez słynnego krakowskiego drukarza i kalwinistę Macieja Wirzbiętę (1523-1605) ${ }^{48}$. Unikatowy egzemplarz zachował się w tzw. konwolucie sofijskim, składającym się z szeregu elementarzy wydanych w Rzeczypospolitej cyrylicą i łacinką na przełomie XVI

Zob. J ung, op. cit., s. 126-131.

Zob. Cohrs, op. cit., s. 169-172.

F. Melanchton, Etliche spruch darynn das gantz Christlich leben gefasset ist. Wittenbergae: Simphoria Reinhart, [przed 1527]. Przedruk: C o h r s, op. cit., t. 2 (1900): Die evangelischen Katechismusversuche aus den Jahren 1527-1528, s. 243-259. Etliche spruch [...] drukowano także jako dodatek do katechizmów J. Brenza (przedruk: ibidem, s. 230) i w poszczególnych wydaniach Betbüchlein M. Lutra (przedruk: ibidem, t. 1 〈1900〉: Die evangelischen Katechismusversuche aus den Jahren 1522-1526, s. 8).

Zob. J ung, op. cit., s. 218.

Można tu np. wymienić K. He ge n d orfer a (1500-1540) Christiana studiosae iuventutis institutio (Haguenau: Johann Setzer, 1526; ostatni rozdział zatytułowany Insignes loci e scripturis sanctis) i J. Pinicianus a (1477/78-1542) Praecepta ac Doctrinae Domini nostri Iesu Christi, parvulis in ludis literariis tradendae (Augustae: Siluanus Otmar, 1529).

Zob. Polonia typographica saeculi sedecimi. Red. A. Kawe cka-Gryczowa. Z. 11. Oprac. ... Wrocław 1981, s. 58, poz. 98. - P 71. 
i XVII wieku ${ }^{49}$. Sądząc $z$ krótkiej przedmowy, jest to druga edycja opublikowanego nieco wcześniej podręcznika Preces seu institutiones. Owa edycja została w bibliografii odnotowana jako niezachowana ${ }^{50}$.

Dwujęzyczny podręcznik Wirzbięty przytacza jedną linię tekstu łacińskiego (złożonego antykwą), jedna - polskiego (szwabachą), tytuły poszczególnych części i rozdziałów podane są tylko po łacinie. W części początkowej szereg fragmentów nie ma tłumaczenia polskiego. Institutio zawiera znacznie rozbudowaną część katechizmową, podzieloną na 4 duże rozdziały: obowiązki chrześcijanina wobec Boga (Quidnam pensi Deo debeant homo Christianus) i wobec bliźniego (Quid proximo suo solvere debeat), o doskonaleniu duszy (Quomodo animus excolendus) oraz o trosce o ciało (Quomodo corpus curandum sit). Liczba ustępów biblijnych u Wirzbięty jest o wiele większa niż u Melanchtona i braci Otho. Pilarczyk uważa, iż drukarz krakowski „prawdopodobnie sam dokonał przekładów zamieszczonych tu psalmów. Jego autorstwa są też zapewne liczne parafrazy wersetów $\mathrm{z}$ wielu ksiag Biblii [...]"51.

Rozdział pierwszy podręcznika (k. A4v-B6) ułożony został w porządku codziennego prywatnego nabożeństwa. Rozpoczyna go modlitwa poranna (inc. „Wszechmogący Boże, który nas, grzeszne, ku początku tego dnia nie naszymi zasługami, ale Twą najświętszą miłością przyść dopuściłeś”), Ojcze nasz, Zdrowaś Maryjo, Wierzę (ze wskazaniem, kto z apostołów dany artykuł wyznania wiary ułożył ${ }^{52}$ ), Invocatio Sancti Spiritus (inc. „Przyjdź, Święty Duchu, napełń Twych serca wiernych”) z modlitwą „Boże, który serca wiernych Świętego Ducha oświeceniem nauczyłeś”. Dalej następuje krótka uwaga o zachowaniu się dziecka w kościele: „Niech wie dziecię kościół nie jaskinią łotrowską być, ale dom modlitwy. A dlatego nie giełdę, nie śmiechy, nie rozpustności będzie sprawował w nim, ale gdy śpiewania

Fotokopia Bibl. Narodowej (Fot.4 .714adl.). Opis konwolutu: A. I. S obolewskij, Dwie bibliograficzeskije riedkosti. „Cztienija w Istoriczeskom obszczestwie Niestora Letopisca” t. 12 (1898). - F. Ko p e r a, Druki polskie $w$ bułgarskim Muzeum Narodowym $w$ Sofii. „Wiadomości Numizmatyczno-Archeologiczne" 1901, nr 2.

50 Zob. Polonia typographica saeculi sedecimi, z. 11, s. 6. W trakcie kwerend w Bibliotece Narodowej udało się ostatnio przypadkiem odnaleźć drugi egzemplarz wydania Elementaria institutio Latini sermonis. Katalog BN notuje ten druk jako modlitewnik polsko-łaciński z XVI w. (sygn. XVI.0.433adl.). Nie posiada on karty tytułowej ani końca, zawiera tylko składki B3-E7 i jest oprawiony wspólnie z XVII-wieczną edycją katechizmu P. Ka ni zj u s za. Egzzemplarze warszawski i sofijski są identyczne pod względem treści, ale mają różną paginację, ponadto warszawski zaznacza księgi biblijne liczbami arabskimi, sofijski zaś - przeważnie rzymskimi. Odnaleziony druk można uznać za zaginioną edycję Preces seu institutiones. Uzupełnia to naszą wiedzę o historii drukarni, której działalność doczekała się już wszechstronnego opracowania przez A. Kawecką-Gryczową.

51 F. Pila r czy k, „Biblia” $w$ elementarzach staropolskich. W zb.: „Nowy Testament” $w$ dziejach $i$ kulturze Europy. 450 rocznica przekładu „Nowego Testamentu” przez Mikołaja Jakubicę na język dolnołużycki. Red. T. J aw or s ki, W. Pyżewi c z. Zielona Góra 2001, s. 192.

52 Podanie imion apostołów spotykamy w szeregu polskich średniowiecznych rękopisów (zob. np. Wy d ra, Rz e p ka, op. cit., s. 24), a także w poszczególnych katechizmach i gramatykach z pierwszej połowy XVI stulecia (zob. np. J. Pinicianus, Brevis institutio de octo partibus orationis. Augustae: Siluanus Otmar, 1522, k. 57). W czasach późniejszych było to zjawisko dość rzadkie w elementarzach polskich i katechizmach zwolenników reformacji, stanowiąc cechę charakterystyczna przeważnie tekstów powstałych w obozie katolickim. 
czas jest, niech czyni to najpoczciwiej. A od śpiewania wolny, niech wyznawa grzechy swe Panu..." (k. A7). Na nabożeństwo codzienne składają się również antyfona Ne reminiscaris Deum (na podstawie Ps 79, 8), psalm pokutny 51 (50), modlitwa Pro cuncto etiam populo ${ }^{53}$, psalmy 67 (66) (Deus misereatur nostri et benedicat nobis) i 8 (Domine Dominator noster), a także szereg modlitw: przed pokarmem i dziękczynna po pokarmie (w obu wypadkach zamieszczono 2 wersje krótką i rozszerzona) oraz przed pójściem do snu. Benedictio mensae brevissima (,Błogosław nas, Panie, i ty dary, których z Twojej szczodrobliwości pożywać mamy [...]”) i krótką wersję Gratiarum actio sumpto cibo („Czynimy Tobie dzięki, wszechmogący Boże, za wszystkie dobrodziejstwa Twe [...]") spotykamy już we wspomnianej książeczce dla laików i dzieci Eyn Bökeschen vor de leyen unde kinder z 1525 roku ${ }^{54}$. Później drukowano ją wielokrotnie jako Biblię laicka ${ }^{55}$.

Rozdział drugi podręcznika (k. B6-C7) zawiera ułożony z cytatów biblijnych spis obowiązków chrześcijanina wobec różnych grup społecznych i kategorii bliźnich. Wirzbięta poprzestaje na 14 grupach („Bliźni człowieczy rozmaici są, $\mathrm{z}$ których najczelniejsze tylko tu wyliczymy"): obowiązki wobec nauczycieli Słowa Bożego i naśladowców tegoż Słowa; dzieci wobec rodziców i rodziców wobec dzieci; w stosunku do władzy świeckiej, przyjaciół i nieprzyjaciół; obowiązki panów wobec poddanych i poddanych wobec panów; w stosunku do najemników, ludzi starszych, biednych, grzeszników, wszystkich chrześcijan.

Kompozycja tego rozdziału przypomina Haustafel albo Tabulae oeconomicae z Małego katechizmu Lutra, jakkolwiek nie wszystkie stany są takie same ${ }^{56}$. W polskich tłumaczeniach nazywano ów rozdział Tablica domowa. Tradycyjnie Haustafel był zbudowany wyłącznie $z$ cytatów biblijnych i nie zawierał żadnego wykładu; tablica stanowiła element strukturalny ewangelickiego Katechizmu heidelberskiego z 1563 r. oraz szeregu katechizmów i ordynacji kościelnych w Niemczech.

Rozdział trzeci podręcznika Wirzbięty (O doskonaleniu duszy; k. C7-E4vin) prawie w całości odpowiada Spruchsammlung braci Otho. Zamianie ulega kolejność poszczególnych fragmentów:

53 Modlitwa składa się z 8 ostatnich strof, czyli z części nierymowanej łacińskiego hymnu Te Deum laudamus, który zazwyczaj nazywano wyznaniem wiary św. Augustyna i św. Ambrożego. Owa część nierymowana $z$ kolei jest ułożona $z$ fragmentów psalmicznych: 27, 9; 144, 2; 122, 3a; 32, 22; 30, 2a. Odmawiana podczas jutrzni, weszła ona w skład hymnu ewentualnie później. Modlitwa zawarta w podręczniku Wirzbięty nie jest tożsama $\mathrm{z}$ wersją Te Deum wydana przez niego w Psałterzu Dawida onego Świętego a wiecznej pamięci godnego Króla i Proroka, teraz nowo na piosneczki po polsku przełożonem [...] (Kraków 1558, k. 176v). W tym samym roku ukazała się wersja łacińska Quo pacto statim a primis annis pueri debeant in Christianismo institui libellus perutilis. Przedruk: Co h r s, op. cit., t. 1, s. 194-241.

55 Zob. Boy er, op. cit., s. 219.

56 Zob. M. Luter, Mały katechizm. W: Ksieggi wyznaniowe Kościoła luterańskiego. Bielsko-Biała 1999, s. 53-55: dla biskupów, proboszczów i kaznodziejów; co winni chrześcijanie nauczycielom i duszpasterzom swoim; o zwierzchności świeckiej; co winni są poddani zwierzchności; dla mężów; dla żon; dla rodziców; dla dzieci; dla pracowników i pracownic domowych oraz dla robotników; dla przełożonych; dla młodzieży; dla wdów; dla wszystkich w zborze.

57 Składka E zawiera tylko 4 karty (wszystkie pozostałe - 8), ale w tekście nie ma braków. Ten rozdział poprzedza Wirzbięta krótką przedmową (k. C7). 


SPRUCHSAMMLUNG
Voluntas Patris
Vita aeterna
Dilectio Dei erga nos
Christi benigna invitatio
Mediator Christi

SPRUCHSAMMLUNG

Voluntas Patris

Vita aeterna

Dilectio Dei erga nos

Mediator Christi

\section{O DOSKONALENIU DUSZY}

Vita aeterna

Voluntas Patris

Mediator Christi

Dilectio Dei erga nos

Christi benigna invitatio

Szereg fragmentów uzupełniono nowymi cytatami biblijnymi. Ustęp o charakterze eschatologicznym Christi venturus iudex Wirzbięta podzielił na 3 osobne części (k. D5v-D7). Spruchsammlung braci Otho został również znacznie poszerzony. Do nowych fragmentów należą: „Armatura animi contra portas inferni” (1 P 5), „contra carnis illecebras” (1 P 2; Rz 13) i „contra mundi amorem” (Jk 4; J 2); „Fides, spes, charitas in Deum habenda” (Syr 2); psalm 30; „Poenitentia non procrastinanda cum sit incerta dies mortis” (Łk 12; Prz 22; Syr 5); „Poenitens vere speret misericordiam” (Syr 23; Pwt 30); „Aeternae damnationis suspecti, ni diligenter caverint” (Łk 6).

W skład trzeciego rozdziału wchodzi także krótki porządek nabożeństwa $\mathrm{z}$ tekstem nicejsko-konstantynopolitańskiego wyznania wiary. Początek karty jest uszkodzony, dlatego nie da się odtworzyć tytułu tego fragmentu. Porządek nabożeństwa zamieszczano w elementarzach oraz w popularnych katechizmach dla dzieci i ludu bardzo sporadycznie. Z XVI-wiecznych źródeł można wymienić Catechismus, tojest Nauke naprzedniejsza Jana Seklucjana ${ }^{58}$. W podręcznikach o zabarwieniu katolickim spotykamy ów porządek po raz pierwszy jako dodatek do polsko-łacińskiego wydania Elementa puerilis institutionis. Pluribus in locis reformata, piisque orationibus ac Doctrina Christiana, nunc recenter aucta ${ }^{59}$.

W trzecim rozdziale Wirzbięta przytacza ponadto dziesięcioro przykazań (na podstawie Księgi Wyjścia), a także ich krótką wersję wierszowaną, ale tylko po lacinie:

Unum cole Deum, nec iures vane per ipsum.

Sabbata sanctifices, habeas in honore parentes.

Non sic occisor, fur, moechus, testis iniquus.

Alterius nuptam, nec rem cipias alienam.

W nieco innej redakcji (,Unum crede Deum [...”) spotykamy ów tetrastych po raz pierwszy w poemacie dydaktycznym Poeniteas cito peccator słynnego angielskiego teologa Wilhelma de Monte (ok. $1140-1213)^{60}$. Zamieszczano go w licznych utworach rymowanych o charakterze pouczajacym ${ }^{61}$, a także w mszałach publikowanych na terenie Niemiec ${ }^{62}$. W wieku XVIII drukowano ten wierszyk cyrylicą

J. Seklu cja n, Catechismus, to jest Nauka naprzedniejsza. Królewiec: [Jan Weinreich], 1547, k. X4v. W edycji z 1549 r. - k. R2.

Elementa puerilis institutionis. Pluribus in locis reformata, piisque orationibus ac Doctrina Christiana, nunc recenter aucta. Kraków: Franciszek Cezary (młodszy) 1713 (Bibl. Jagiellońska, Cim.0.1325). Edycja drukowana: Poeniteas cito, cum commento: Libellus de modo poenitenti et confitendi. [Paris]: Antoine Caillaut, [ok. 1492], k. d2.

Zob. Joseps Sündenspiegel. Eine niederdeutsche Lehrdichtung des 15. Jahrhunderts. Kommentierte Textausgabe von E. Schütz. Köln-Wien 1973, s. 344.

Zob. L. K. W alt er, Missale Moguntinum und Missale Romanum. Missalien in den Beständen der 
i głagolica w elementarzach wydawanych przez Kongregację Propagandy Wiary dla katolików obrządku wschodniego ${ }^{63}$.

Rozdział czwarty podręcznika Wirzbięty (k. F-F7v) zawiera ułożone z cytatów biblijnych przepisy, jak należy troszczyć się o ciało: „Somnolentia fugienda” (Prz 20), „Lingua ne detrahat” (Syr 28), „Spurci sermones vitandi” (Ef 4), „Sermo frenandus” (Prz 10; 13), „Oculi a comptis auertendi” (Syr 9), „Aures audiant turpia” (Syr 28), „Manus labore exercendae” (1 Tes 4), „Pedibus quomodo utendum” (Syr 4), „Cor diligenter custodiendum” (Syr 4), „Affectus domandi” (Ga 5), „Exemplum humilitatis” (Łk 1), „Animae volentis solui a corpore precatio” (kantyk Symeona). Ten wybór ustępów biblijnych przypomina tzw. reguły przyzwoitości (Anstandsregeln), spotykane na terenie Niemiec w licznych utworach katechetycznych, np. w książeczce niemieckiego humanisty związanego z poznańską Akademią Lubrańskiego, Krzysztofa Hegendorfera - De instituenda vita et corrigendis moribus iuventutis paraenesis $^{64}$. Nie należą one sensu stricto do popularnego w XVI w. gatunku literatury o zasadach cywilizowanego zachowania się.

Rozdział czwarty podręcznika zamykają modlitwy: Jozafata przeciwko wrogom (2 Krn 20, 6-12), ofiarowanie się Bogu (inc. „In manus ineffabilis misericordiae tuae commendo animam meam" - tylko w wersji łacińskiej ${ }^{65}$ i pieśń błagalna Manassesa, umieszczana jako zakończenie 2 Księgi Kronik, zaliczanej przez Kościoły protestanckie do apokryfów. Ciekawą paralelę stanowi słynna Betbüchlein Lutra, w której wydaniu z 1525 r. tekst Ein schön andächtigs Gebet des Königs Manasse von Jerusalem pełni funkcję modlitwy końcowej ${ }^{66}$. Niewykluczone, że i w wypadku podręcznika Wirzbięty modlitwa ta zamykała całość ${ }^{67}$.

Elementarz Wirzbięty z $1575 \mathrm{r}$. to dzieło oryginalne zarówno pod względem układu, jak i doboru ewentualnych źródeł. Do ich liczby, oprócz już wspomnianych, mogła należeć i tzw. Tabula z Brevis institutio de octo partibus orationis ${ }^{68}$ Johannesa Pinicianusa, nauczyciela $z$ Augsburga. Zawiera ona m.in. spotykane u Wirzbięty: wierszyk Unum crede Deum [...] i wybór modłów liturgicznych (Quomodo cum sacerdote ad missam orandum). Materiał „Spruchbücher” był przeznaczony do uczenia się go na pamięć; podręcznik Wirzbięty mógł służyć tym samym celom, łącząc naukę łaciny $\mathrm{z}$ duchową formacją młodych wyznawców Kościoła reformowanego.

Zaproponowany w podręczniku Wirzbięty model materiału religijnego nie za-

Hofbibliothek und der Stiftsbibliothek Aschaffenburg. „Würzburger Diözesangeschichtsblätter” t. 62/63 (2001), s. 42-43.

Bukwar' sławienskij pismieny priepodobnago Kiriłła sławianom episkopa napieczatan. Wyd. 1: Rim 1739; wyd. 2: Rim 1753.

64 K. Hegend orfer, De instituenda vita et corrigendis moribus iuventutis paraenesis. Haganoae: Johannes Secerius, 1529.

65 Układ tej modlitwy jest bardzo podobny do Modlitwy do wszystkich aniołów Ge r tru dy Mi e s zkówny, jakkolwiek nie tożsamy.

66 Zob. Cohrs, op. cit., t. 1, s. 8.

67 W druku Wirzbięty brakuje końca. Modlitwa Manassesa obejmuje karty F6-F7v. Możliwe, że druk zawierał składki A8-F8.

68 J. Pinicianus, Brevis institutio de octo partibus orationis. Augustae: Siluanus Otmar, 1522, k. $57-59 v$. 
domowił się w Polsce na stałe. Stosunkowo niewiele zachowało się również elementarzy wzorujących się na Enchiridionie Lutra. W wieku XVII mamy zaledwie 2 przykłady: podręcznik Pawła Głodnego (Paulus Glodius; 1531-1606), luterańskiego pastora $z$ Wrocławia ${ }^{69}$, oraz niedatowany elementarz wrocławski $z$ drugiej połowy stulecia ${ }^{70}$. Liczbowo przeważały elementarze naśladujące model katechezy parafialnej. $Z$ czasem uzupełniano go mniej lub bardziej rozległymi katechizmami w postaci pytań i odpowiedzi. Kontynuacją tej dość konserwatywnej tradycji stają się w XIX w. tanie groszówki albo abecadlniki dla ludu ${ }^{71}$. Także w innych tradycjach konfesyjnych wybór tekstów religijnych wchodzących w skład elementarzy cechował się dużym konserwatyzmem: ulega on nieznacznemu rozbudowaniu w XVII i XVIII stuleciu, lecz jego część podstawowa pozostaje bez zmian. Ta obserwacja jest słuszna nie tylko dla obszaru chrześcijaństwa zachodniego ${ }^{72}$, ale również i wschodniego ${ }^{73}$.

Abstract

MARGARITA A. KORZO Institute of Philosophy of the Russian Academy of Sciences, Moscow

\section{ON RELIGIOUS TEXTS IN $16^{\mathrm{TH}}$ C. POLISH PRIMERS}

A characteristic feature of the early modern primers of all confessional shades was a combination of grammatical material with a fairly large selection of religious texts, which served a dual role: they contributed to religious consciousness formation of children and helped in acquisition of reading. A comparison of those selections allows to specify four models which dominated in the $16^{\text {th }}$ century. The earliest one is the so-called liturgical model and the model of the medieval parish catechetical instruction (Ortografia 〈Ortography〉 by Stanisław Zaborowski, 1514-1515; Nauka ku czytaniu dziatkam [...] 〈A Study of Reading for Children [...]〉 by a Poznan printer Piotr Sextilis, 1556). The Reformation led to the creation of two more models: ABC-books, which followed Small Catechism of Martin Luther (Nauka krótka ku czytaniu pisma polskiego. Kraków: Jan Januszowski, the second half of the $16^{\text {th }}$ century) and primers arranged in the genre of "Spruchbücher" (Elementarz polsko-taciński 〈A Polish-Latin Primer〉. Kraków: Łazarz Andrysowic, ca. 1550; Elementaria institutio Latini sermonis, et pietatis Christianae. Kraków: Maciej Wirzbięta, 1575). In the $17^{\text {th }}$ and $18^{\text {th }}$ centuries numerically dominated textbooks imitated the model of the medieval parish catechetical instruction, which has been extended in catechisms in the form of questions and answers.

Catechism, to jest Summa wiary chrześciańskiej [...]. Wyd. 3. Breslaw: Georg Baumann, 1615 (Bibl. Narodowa, XVII.2.560).

[M. Gutthäter Dobracki (młodszy)], Elementarz Szkoły Wrocławskiey Polskiej świeżo wystawionej, z nabożeństwem ranym, południowym i wieczornym, kwoli młodzi zaprawiajacej się $w$ polski język spisany. Opis podręcznika i przedruk fragmentów: B. Kocowski, Zagadkowy elementarz wrocławski. „Rocznik Biblioteki Narodowej” t. 4 (1968).

Zob. np. [J. K. Mi ka], Groszówka dla dzieci niechodzacych do szkoły. Tarnów: Józef Karnstädt, 1838.

Zob. J. M üll er, Quellenschriften und Geschichte des deutschsprachigen Unterrichts bis zur Mitte des 16. Jahrhunderts. Mit einer Einf. von M. Rössing-Hager. Gotha 1882, s. 210 n. I. Willke, ABC-Bücher in Schweden. Ihre Entwicklung bis Ende des 19. Jahrhunderts und ihre Beziehungen zu Deutschland. Lund 1965, s. 68. - H. M üll er, Fibel (ABC-Buch), s. 695.

Zob. M. A. K or z o, O strukturie i sodierżanii bukwarnych katiechizisow moskowskoj pieczati XVII - naczała XVIII wieka. „Sławianowiedienije” 2005, nr 2. 